\title{
Implication of C-type natriuretic peptide derived from vascular endothelial cells on blood pressure regulation
}

\author{
Kazuwa Nakao ${ }^{1 *}$, Kazuhiro Nakao ${ }^{2}$, Koichiro Kuwahara $^{3}$, Kenji Kangawa ${ }^{2}$ \\ From 7th International Conference on cGMP Generators, Effectors and Therapeutic Implications \\ Trier, Germany. 19-21 June 2015
}

\section{Clinical background}

We previously reported the secretion of C-type natriuretic peptide (CNP) from vascular endothelial cells and proposed the existence of vascular natriuretic peptide system composed of endothelial CNP and vascular smooth muscle guanylyl cyclase-B (GC-B), the selective receptor for $\mathrm{CNP}$, and implicated in the regulation of vascular tone, remodeling and regeneration [1-5]. However the functional role of the natriuretic peptide system is still unclear, because markedly short stature of CNP or GC-B knockout mice could be hardly studied for blood pressure regulation [6].

In the present study, we have assessed the functional significance of this system in the regulation of blood pressure in vivo using vascular endothelial cell-specific CNP knockout (CNP ecKO) and vascular smooth muscle cell-specific GC-B knockout (GC-B smcKO) mice generated using the Cre/loxP system. These mice showed neither the skeletal abnormality nor the early mortality observed in systemic CNP or GC-B knockout mice [6]. CNP ecKO mice exhibited significantly increased blood pressure and an enhanced acute hypertensive response to nitric oxide synthetase inhibition by NG-nitro-L-arginine methyl ester (L-NAME). In addition, acetylcholineinduced, endothelium-dependent vasorelaxation was impaired in rings of mesenteric artery isolated from CNP ecKO mice. Pulmonary vascular endothelial cells from CNP ecKO mice showed enhanced expression of genes encoding endothelin-1 (ET-1). In contrast, GC-B smcKO mice exhibited blood pressure similar to control mice, and acetylcholine-induced vasorelaxation was preserved

\footnotetext{
* Correspondence: nakao@kuhp.kyoto-u.ac.jp

${ }^{1}$ Medical Innovation Center, Kyoto University Graduate School of Medicine, Kyoto, Japan

Full list of author information is available at the end of the article
}

in their isolated mesenteric arteries. Nonetheless, CNPinduced acute vasorelaxation was nearly completely abolished in mesenteric arteries from GC-B smcKO mice.

\section{Conclusion}

These results demonstrate that endothelium-derived CNP contributes to the chronic regulation of vascular tone and systemic blood pressure by maintaining endothelial function independently of vascular smooth muscle GC-B and indicate the implication of the vascular natriuretic peptide system in blood pressure control.

\section{Authors' details}

'Medical Innovation Center, Kyoto University Graduate School of Medicine, Kyoto, Japan. ${ }^{2}$ National Cerebral Cardiovascular Center, Kyoto, Japan. ${ }^{3}$ Department of Cardiovascular Medicine, Kyoto University Graduate School of Medicine, Kyoto, Japan.

\section{Published: 2 September 2015}

\section{References}

1. Komatsu $Y$, Nakao $K$, Itoh $H$, Suga $\mathrm{S}$, Ogawa $\mathrm{Y}$, Imura $\mathrm{H}$ : Vascular natriuretic peptide. Lancet 1992, 340:622.

2. Suga S, Nakao K, Itoh H, Komatsu Y, Ogawa Y, Hama N, Imura H: Endothelial production of C-type natriuretic peptide and its marked augmentation by transforming growth factor-beta. Possible existence of "vascular natriuretic peptide system". J Clin Invest 1992, 90:1145-1149.

3. Itoh H, Suga S, Ogawa Y, Komatsu Y, Tamura N, Igaki T, Yamashita J, Ikeda T, Doi K, Chun TH, Inoue M, Matsuda K, Yoshimasa T, Ueda M, Ban T, Nakao K: Significance of vascular natriuretic peptide system in vascular remodeling in humans and its application to gene therapy. Ann N Y Acad Sci 1997, 811:533-541.

4. Igaki T, Itoh H, Suga Sl, Hama N, Ogawa Y, Komatsu Y, Yamashita J, Doi K, Chun TH, Nakao K: Effects of intravenously administered C-type natriuretic peptide in humans: comparison with atrial natriuretic peptide. Hypertens Res 1998, 21:7-13.

5. Doi K, Ikeda T, Itoh H, Ueyama K, Hosoda K, Ogawa Y, Yamashita J, Chun TH, Inoue M, Masatsugu K, Sawada N, Fukunaga Y, Saito T, Sone M, Yamahara K, Kook H, Komeda M, Ueda M, Nakao K: C-type natriuretic peptide induces redifferentiation of vascular smooth muscle cells with 
accelerated reendothelialization. Arterioscler Thromb Vasc Biol 2001,

21:930-936.

6. Chusho H, Tamura N, Ogawa Y, Yasoda A, Suda M, Miyazawa T, Nakamura K, Nakao K, Kurihara T, Komatsu Y, Itoh H, Tanaka K, Saito Y, Katsuki M, Nakao K: Dwarfism and early death in mice lacking C-type natriuretic peptide. Proc Natl Acad Sci USA 2001, 98:4016-4021.

doi:10.1186/2050-6511-16-S1-A28

Cite this article as: Nakao et al:: Implication of C-type natriuretic peptide derived from vascular endothelial cells on blood pressure regulation.

BMC Pharmacology and Toxicology 2015 16(Suppl 1):A28.

Submit your next manuscript to BioMed Central and take full advantage of:

- Convenient online submission

- Thorough peer review

- No space constraints or color figure charges

- Immediate publication on acceptance

- Inclusion in PubMed, CAS, Scopus and Google Scholar

- Research which is freely available for redistribution

Submit your manuscript at www.biomedcentral.com/submit
C Biomed Central 